\title{
RESEARCHPAPER \\ Bio-efficacy of dinotefuran 20 per cent SG against sucking insect pests of okra
}

\author{
VENKATESHALU AND MAHESH MATH
}

Department of Entomology, College of Horticulture, University of Horticultural Sciences, BAGALKOT (KARNATAKA) INDIA (Email: maheshento@gmail.com)

Email : venk0910@gmail.com

Article Info : Received : 01.02.2017; Revised : 08.03.2017; Accepted : 20.03 .2017

Evaluation of dinotefuran 20 per cent SG against sucking pests of okra was undertaken in an experimental block at Agricultural Research Station, Bheemarayanagudi during Rabi 2012-13. The test chemical, dinotefuran 20\% SG @ $30 \mathrm{~g}$ a.i. per ha is most effective dosage for the management of sucking pests like leafhopper, A. biguttula, aphids, A. gossypii, thrips, T. tabaci and whiteflies, B. tabaci and also recorded higher okra fruit yield of $93.01 \mathrm{q}$ per ha. Apart from this, dinotefuran 20 per cent SG at varied dosages is quite safer to natural enemies. So, dinotefuran 20\% SG @ $30 \mathrm{~g}$ a.i. per ha can be used for the effective management of sucking pests and for realizing higher okra fruit yield.

Key words : Bioefficay, Dinotefuran, Sucking insect pests, Okra

How to cite this paper : Venkateshalu and Math, Mahesh (2017). Bio-efficacy of dinotefuran 20 per cent SG against sucking insect pests of okra . Asian J. Bio. Sci., 12 (1) : 8-14.DOI : 10.15740/HAS/AJBS/12.1/8-14. 